Brit. F. vener. Dis. (1971) 47, 48

\title{
The problem of venereal diseases in Singapore
}

\author{
R. S. MORTON* \\ Royal Hospital, Sheffield
}

The island Republic of Singapore has an area of 225 square miles. The population, which has doubled since 1952, now numbers two million, of which nearly 50 per cent. are under 21 years of age.

Economically the country is thriving. The gross national product has increased by over 10 per cent. per annum in recent years; employment rates and per capita incomes and investments are all rising, urban renewal schemes, some in conjunction with industrial development, will have re-housed three quarters of a million between 1961 and the end of 1970.

Although prosperity has accelerated the spread to Singapore of the world's increasingly homogeneous styles and attitudes, social changes at the family and individual level are less apparent than in Western countries - at least to date. In contrast to the West, for example, prosperity has not meant earlier marriage. The average age for girls to marry remains high and is actually rising, from 23.1 years in 1962 to 23.9 in 1969. Furthermore, social pathology patterns, well recognized in the West, are not a marked feature. Juvenile delinquency is not a growing problem and crimes involving violence have fallen from about 3,000 to 2,000 per annum in recent years.

Factors more directly relevant to the incidence of venereal disease concern the presence of British Commonwealth forces and the increase in Singapore's own army, navy, and airforce. Tourist arrivals are growing; there were 251,000 in 1968 and 366,000 in 1969. A particularly important factor is the growing seaport trade; in 1968, 32,000 ocean-going ship arrivals are estimated to have brought in a potential one million seafarers.

In the area of sexual attitudes and behaviour, family traditions prevail and 'permissiveness' is not a general feature. Traditional Eastern prostitution, however, appears to have expanded to a greater degree than can be accounted for by population growth alone. It is estimated that there are between 3,500 and 5,000 female and about 200 male prostitutes.

Received for publication June 10, 1970

*W.H.O. V.D. Control Consultant, Singapore, November 1, 1969, to April 30, 1970
Such population and socio-economic findings are compatible with substantial levels of venereal infection.

The size of the problem

Figs 1 and 2 (opposite) show the incidence of syphilis and gonorrhoea in the two public clinics of Singapore.

\section{SYPHILIS}

Infectious syphilis reached its lowest level in 1965 with only 97 cases, but the incidence had increased to 229 by 1969 . Latent syphilis declined to 320 cases in 1968, but both early (under 4 years) and late latent forms increased to a total of 502 cases in 1969. Late syphilis has declined steadily and there were only seventeen cases in 1969. Cases of infantile syphilis have been numbered in single figures for a decade, and the trend in late congenital syphilis parallels that of latent acquired infections.

\section{GONORRHOEA}

The incidence of gonorrhoea declined from the postwar peak of 3,900 cases to 2,339 in 1955 ; there have since been marked annual fluctuations, and in 1969 there were 1,879 cases. The numbers of cases of gonococcal ophthalmia neonatorum have also fluctuated; there were 104 cases in 1967 and 86 in 1969, when 43,000 births were recorded.

\section{CHANCROID}

Cases diagnosed as chancroid have decreased; they numbered 277 in 1969.

LYMPHOGRANULOMA VENEREUM

1969 was the first year in which no cases were recorded.

NON-GONOCOCCAL URETHRITIS

This reached a peak in 1961 with 1,908 cases; in 1969 there were only 331 .

TRICHOMONIASIS AND CANDIDOSIS

These are being seen more frequently. 


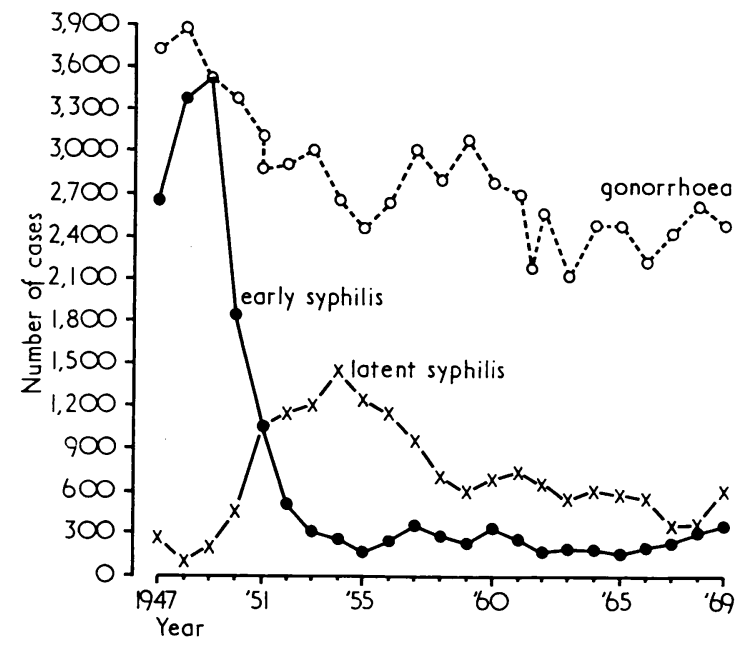

F I G, 1 Incidence of gonorrhoea and syphilis in Singapore's public clinics, 1947-69

\section{SCABIES}

This remains constant.

INFESTATION WITH PUBIC LICE

This is said to be less frequent.

These figures for the various diseases show that the expected general increase in cases of sexually transmitted diseases was not demonstrated by attendances at the two public clinics. It was accordingly decided to obtain an estimate of the cases seen in private practice.

216 of Singapore's 500 private general practitioners were selected at random and invited to complete a questionnaire (Table I), and 124 (62 per cent.) of the 200 doctors available replied.

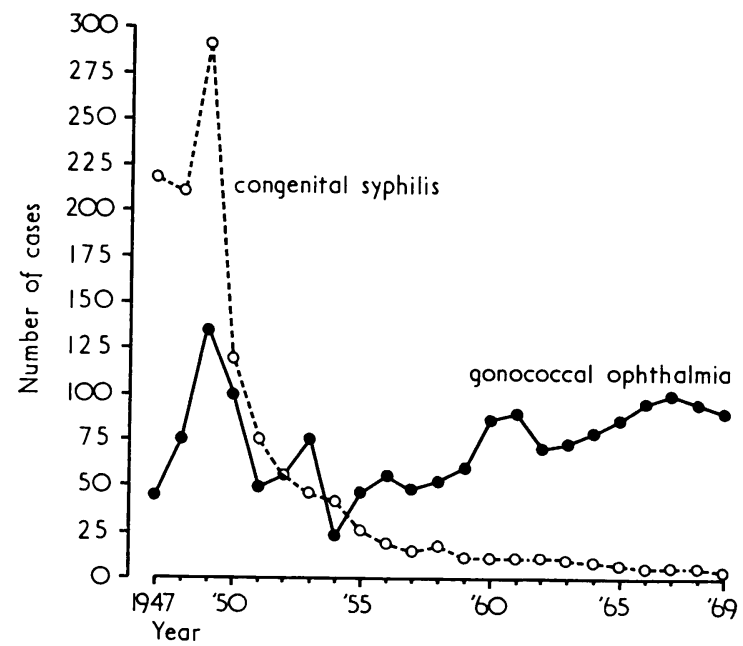

F I G. 2 Incidence of congenital syphilis and gonococcal ophthalmia in Singapore's public clinics, 1947-69

Table II (opposite) shows the numbers and types of cases treated privately by those replying. The response rate of 62 per cent. allows of confident extension of the findings to a calculation of a theoretical minimum number of cases dealt with by the total of 500 private practitioners in 1969. The extrapolated figures are set out in Table III (overleaf).

By adding these figures to those of cases seen in the public clinics and those made available by Commonwealth services, the minimum case rates per 100,000 for 1969 were calculated (Table IV, overleaf).

It is evident that the public clinics deal with only a fraction of the various conditions diagnosed. In contrast to these minimal estimated case rates

\section{TABLE I Questionnaire sent to private general practitioners}

How many patients do you estimate you treated for the following conditions?

(a) In January this year (1970)

(b) In the whole of last year (1969)

(1) Females

(a) Proven gonorrhoea

(b) Suspected gonorrhoea

(c) Syphilis

(2) MALES

(d) Other sexually transmissible diseases (trichomoniasis, vaginal thrush, genital warts, etc.)

(a) Proven gonorrhoea

(b) Suspected gonorrhoea

(c) Non-gonococcal urethritis

(d) Syphilis

(c) Other sexually transmissible diseases (e.g. chancroid, LGV, genital warts, crabs, etc.)

(3) BOTH SEXES

(a) How many of all these patients were known to you as sex contacts of infected patients?

(b) How many blood tests for syphilis did you request?

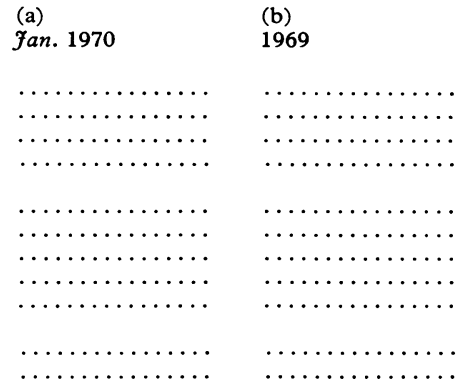

(4) REMARKS 
TABLE II Response to private practitioners' survey

\begin{tabular}{|c|c|c|c|}
\hline \multicolumn{2}{|c|}{$\begin{array}{l}\text { No of questionnaires sent out } \\
\text { Returned 'Gone away' } \\
\text { Remainder }\end{array}$} & \multicolumn{2}{|l|}{$\begin{array}{r}216 \\
16 \\
200\end{array}$} \\
\hline \multicolumn{2}{|c|}{ Returned with data } & \multicolumn{2}{|c|}{124 (62 per cent.) } \\
\hline REPLiES & & $\begin{array}{l}\text { fan. } 1970 \\
(120)\end{array}$ & 1969 (114) \\
\hline Sex & Disease & No. of cases & \\
\hline Females & $\begin{array}{l}\text { (a) Proven gonorrhoea } \\
\text { (b) Suspected gonorrhoea } \\
\text { (c) Syphilis } \\
\text { (d) Other sexually trans- } \\
\text { missible diseases }\end{array}$ & $\begin{array}{r}55 \\
147 \\
5 \\
154\end{array}$ & $\begin{array}{r}412 \\
1,022 \\
64 \\
1,180\end{array}$ \\
\hline Males & $\begin{array}{l}\text { (a) Proven gonorrhoea } \\
\text { (b) Suspected gonorrhoea } \\
\text { (c) Non-gonococcal } \\
\text { urethritis } \\
\text { (d) Syphilis } \\
\text { (e) Other sexually transmis- } \\
\text { sible diseases }\end{array}$ & $\begin{array}{r}161 \\
397 \\
182 \\
22 \\
83\end{array}$ & $\begin{array}{r}1,641 \\
3,228 \\
1,180 \\
184 \\
535\end{array}$ \\
\hline BOTH SEXES & $\begin{array}{l}\text { (a) Contacts` } \\
\text { (b) Serological tests for } \\
\text { syphilis }\end{array}$ & $\begin{array}{l}148 \\
165\end{array}$ & $\begin{array}{l}1,911 \\
1,363\end{array}$ \\
\hline
\end{tabular}

*The question was poorly worded and hence not understood by many The figures given are considered invalid.

TAB LE II I Private practitioners' survey. Theoretical minimum number of cases in 1969

\begin{tabular}{|c|c|c|}
\hline Sex & Disease & No. of cases \\
\hline Females & $\begin{array}{l}\text { Proven gonorrhoea } \\
\text { Suspected gonorrhoea } \\
\text { Syphilis } \\
\text { Other sexually transmissible } \\
\text { diseases (trichomoniasis, va- } \\
\text { ginal thrush, genital warts, } \\
\text { etc.) }\end{array}$ & $\begin{array}{r}1,030 \\
2,555 \\
160 \\
2,950\end{array}$ \\
\hline MALES & $\begin{array}{l}\text { Proven gonorrhoea } \\
\text { Suspected gonorrhoea } \\
\text { Non-gonococcal urethritis } \\
\text { Syphilis } \\
\text { Other sexually transmissible } \\
\text { diseases (e.g. chancroid, LGV, } \\
\text { genital warts, crabs, etc.) }\end{array}$ & $\begin{array}{r}4,102 \\
8,070 \\
2,950 \\
460 \\
1,337\end{array}$ \\
\hline BOTH SEXES & $\begin{array}{l}\text { Contacts } \\
\text { Serological tests for syphilis }\end{array}$ & 3,405 \\
\hline
\end{tabular}

«See footnote Table II

TABLE IV Estimated minimum case rates per 100,000 population in Singapore 1969

\begin{tabular}{lll}
\hline Total syphilis & 72 \\
\hline Proven gonorrhoea & 373 \\
Non-gonococcal urethritis & $\frac{175}{277}$ \\
\hline Total urethritis in males & 877 \\
\hline
\end{tabular}

(Table IV), the proportions diagnosed in the public $\vec{\nexists}$ clinics are as follows:

Syphilis-39 per 100,000 (54 per cent.); proven gonorrhoea-94 per 100,000 (24 per cent.); non- $\frac{\bar{\sigma}}{\bar{c}}$ gonococcal urethritis-16 per 100,000 ( 9 per cent.): total urethritis in males-37 per 100,000 (10 per cent.).

\section{Nature of the problem}

With some clearer idea of the size of the problem an $\bar{\omega}$ attempt was next made, by analysis of the public clinic case notes, to determine its nature.

No notably high or increasing incidence among. patients aged 15 to 19 years was found. The male: female sex ratio of recently infected patients had improved over the years to $3: 1$ in 1969. A marital status study for the same year showed that 64 per cent. $\vec{T}$ of males and 34 per cent. of females were single. $\mathbb{D}$ The incidence of infection in the various racial groups is set out in Table V and compared with the racial distribution of the population as a whole.

TABLE V Percentage ethnic groups in Singapor general and clinic populations, 1969

\begin{tabular}{|c|c|c|}
\hline Race & General population & Clinic patient \\
\hline $\begin{array}{l}\text { Chinese } \\
\text { Malays } \\
\text { Indians and Pakistanis } \\
\text { Others (mainly European) }\end{array}$ & $\begin{array}{r}75 \cdot 0 \\
14 \cdot 5 \\
8 \cdot 1 \\
3 \cdot 0\end{array}$ & $\begin{array}{r}52 \cdot 0 \\
18 \cdot 0 \\
25 \cdot 0 \\
5 \cdot 0\end{array}$ \\
\hline
\end{tabular}

Of the 3,364 cases of syphilis, gonorrhoea, and chancroid seen in 1969,143 (4.2 per cent.) were contracted abroad. Nearly 97 per cent of all men with gonorrhoea claimed to have been infected by $a \dot{\delta}$ prostitute.

Of 111 consecutive prostitutes, $36(32.4$ per cent.)응 were using oral contraceptives as against 37 of $100>$ patients attending a dermatology clinic.

The high incidence of gonococcal ophthalmia $N_{\sigma}$ neonatorum, 1 case per 500 births, is believed to be the best available indication of the size of the female $\mathrm{N}$ reservoir of infection. The significance of gonorrhoea $\omega$ as a cause of sterility in women could not be ascer-? tained, but local gynaecologists stated that it wase their general impression that sub-acute and chronic pelvic sepsis was encountered more frequently than their experience in the United Kingdom had led $\frac{0}{3}$ them to expect.

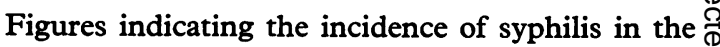
population and in some groups 'at risk' are presented in Table VI (opposite). 
TABLE VI Syphilis survey, 1969

\begin{tabular}{|c|c|c|c|}
\hline \multirow[b]{2}{*}{ Persons examined } & \multirow{2}{*}{$\begin{array}{l}\text { Number } \\
\text { tested }\end{array}$} & Reactive Sera & \multirow[b]{2}{*}{ Per cent. } \\
\hline & & No. & \\
\hline Expectant mothers & 25,584 & 207 & $0 \cdot 8$ \\
\hline Blood donors & 31,433 & 440 & $1 \cdot 4$ \\
\hline Skin patients & 20,379 & 268 & $1 \cdot 3$ \\
\hline $\begin{array}{l}\text { Seamen } \\
\text { Trainee seamen (15-16 yrs) }\end{array}$ & $\begin{array}{l}685 \\
421\end{array}$ & $\mathrm{Nil}^{46}$ & $\begin{array}{l}6 \cdot 7 \\
\text { Nil }\end{array}$ \\
\hline Prisoners & 413 & 25 & $6 \cdot 1$ \\
\hline $\begin{array}{r}\text { Juvenile delinquents } \begin{array}{l}\text { Male } \\
\text { Female }\end{array}\end{array}$ & $\begin{array}{r}52 \\
147\end{array}$ & $\mathrm{Nil}^{2}$ & $\begin{array}{l}3 \cdot 9 \\
\text { Nil }\end{array}$ \\
\hline $\begin{array}{r}\text { New prostitutes } \text { Male } \\
\text { Female }\end{array}$ & $\begin{array}{r}39 \\
248\end{array}$ & $\begin{array}{l}10 \\
44\end{array}$ & $\begin{array}{r}5 \cdot 5 \\
17 \cdot 7\end{array}$ \\
\hline & 79,401 & 1,042 & $1 \cdot 18$ \\
\hline
\end{tabular}

In the large mental hospital $4 \cdot 1$ per cent. of over 2,000 in-patients had evidence of insanity associated with syphilis. In 1967, seventeen of 10,618 deaths were certified as due to syphilis.

Many features of the problem were investigated, including prostitution, contact tracing, health education, laboratory services, and the sensitivity of local strains of gonococci, and undergraduate and postgraduate medical education were surveyed in detail. From the total review a comprehensive programme of development aimed at improved control of the venereal diseases in Singapore has been formulated and a start has already been made to put it into operation.

\section{Summary}

The problem of venereal diseases in Singapore has been investigated, under the auspices of WHO, by the study of cases seen at the two public clinics; by surveys of cases seen by private practitioners; and by investigation of 'at risk' groups. About one half of the cases of syphilis, but fewer than one quarter of the cases of gonorrhoea and one tenth of those of non-gonococcal urethritis were diagnosed in the public clinics. Occurrence of ophthalmia neonatorum at the rate of one case per 500 births indicated a substantial reservoir of untreated gonorrhoea in women. Investigations of contact tracing, laboratory service, postgraduate education, and other features were carried out, and a plan has been put into practice for improved control of venereal disease.

I am indebted to my counterpart Dr. Lawrence Leong, S.M.O., Middle Road Hospital, Singapore, for his enthusiastic help, to Maj. R. N. T. Thin, R.A.M.C. for his co-operation, and to Dr. Pierre Durel for acting as my locum tenens in Sheffield.

\section{La problème des maladies vénériennes à Singapour} SOMMAIRE

Sous les auspices de l'OMS, le problème des maladies vénériennes à Singapour a été examiné; par l'étude des cas vus dans deux cliniques publiques; par l'examen des cas vus par des médecins praticiens privés, et par une recherche sur des groupes exposés. La moitié à peu près des cas de syphilis, mais moins d'un quart des cas de gonococcie, et un dixième des cas d'urétrites non gonococciques furent diagnostiqués dans les cliniques publiques. Le fait que l'ophtalmie des nouveau-nés survient dans la proportion de 1 cas pour 500 naissances, indique que les femmes gonococciques non traitées représentent un important réservoir d'infection. Une investigation sur la recherche des contacts, sur les services de laboratoire, sur l'éducation post-universitaire, et sur d'autres points, a été entreprise; un plan a été mis en application pour améliorer la lutte contre les maladies vénériennes. 